\title{
СЛОЖНЫЕ НОВООБРАЗОВАНИЯ \\ В ЭЛЕКТРОННЫХ РОССИЙСКИХ СМИ
}

\author{
COMPOUND INNOVATIONS IN ONLINE RUSSIAN MASS MEDIA
}

\author{
ЛАРИСА РАЦИБУРСКАЯ
}

\begin{abstract}
The article considers the structure and functions of compound innovations in online Russian mass media. These innovations are composed by the usual means of pure composition and root affixation. Contaminated innovations, which are non-standard in structure, are also analyzed. The factors contributing to the expressiveness of innovations are singled out: irregularity of derivational structure, non-usual combinations of constituent parts of innovations, play upon precedent phenomena.
\end{abstract}

Лариса Рацибурская, Национальный исследовательский Нижегородский государственный университет им. Н.И. Лобачевского, Нижний Новгород - Россия, racib@yandex.ru

Интернет, по словам ученых, „является самым широким, самым разнообразным и самым сложным коммуникативным пространством, средством и каналом связи, придуманным и созданным когда-либо человеком"1. Присущие средствам массовой коммуникации функции сообщения и воздействия усиливаются в сетевых масс-медиа благодаря более широким интерактивным возможностям последних. По мнению ученых, „в СМИ функция воздействия, убеждения начинает вытеснять остальные языковые функции (например, информирования) и средства массовой информации превращаются в средства массового воздействия" 2 . Действенным средством экспрессивизации интернет-текста являются новообразования, значительное число которых представлено сложными конструкциями.

В электронных СМИ преобладают сложные новообразования, созданные способом чистого сложения. Они создаются, как правило, сложением полных основ: „Наградоначальник. Владимир Путин воздал ордена и медали по заслугам перед Отечеством" (10.12.2015, http://www.kommersant.ru/doc/2874126) - награда + начальник; „Кукловывод. Нефтяная компания «ЛУКОЙЛ» выселяет детский театр из центра

1 Б. Т о ш о в и ч, Интернет-стилистика, Москва 2015, с. 29.

2 С.В. И л ь я с о в а, Л.П. А м и р и, Языковая игра $в$ коммуникативном пространстве СМИ и рекламы, Москва 2015, с. 11. 
Москвы" (27.01.2011, http://www.newizv.ru/society/2011-01-27/140047kuklovyvod.html) - кукла + вывод; „Правила правокачания. В России крепнет новая форма объединения граждан. Они не ведут людей на оппозиционные митинги и не пикетируют судов. В их поле зрения - собственная среда обитания и местные проблемы" (15.10.2012, http://www.kommersant.ru/doc/2040115) - право + качание.

В качестве одной из основ при чистом сложении могут выступать имена собственные (или их части), а также аббревиатуры: „Петродеградация. Лев Лурье - о провинциализации культурной столицы России" (17.12.2012, http://www.kommersant.ru/doc/2087160) - Петроград + деградащия; „Энхаэлозависимость. Как отразится на клубах КХЛ возвращение лидеров за океан" (17.01.2013, http://www.mk.ru/sport/ 2013/01/17/799647-enhaelozavisimost.html) - энхаэл (НХЛ) + зависимость; „Росалкогольпровокация. Почему капитан ФСБ оказался за решеткой после встречи с главным "водочным» чиновником" (15.11.2015, http://www.mk.ru/social/2015/11/15/ pochemu-kapitanfsb-okazalsyazareshetkoy-poslevstrechi-s-glavnym-vodochnym-chinovnikom.html)

- росалкоголь + провокация.

Экспрессивность и оценочность сложных новообразований типовой структуры, созданных узуальными способами, могут быть связаны с непривычным, неузуальным сочетанием исходных основ, а также с семантикой мотивирующих (провокация, деградация, зависимость) и с теми реалиями, которые ассоциируются с исходными словами и с новообразованиями. Экспрессия может быть контекстуально и ситуативно обусловленной.

Некоторые сложные новообразования созданы путем заменительного словообразования, при котором в исходном слове заменяется корневая морфема или неморфемная часть и которое исследователи обычно относят к неузуальным способам: „Сетепредставление. Андрей Муров и Олег Бударгин поспорят за пост гендиректора «Российских сетей»" (11.01.2013, http://www.kommersant.ru/doc/2102594) - исходное светопреставление; „Фальшивотаблетчики. О фармакологических фальшивках ходит немало мифов" (21.01.2013, http://www.itogi.ru/ delo/2013/3/186102.html) - исходное фальшивомонетчики; "Турецкопойманные. Россию обвинили в поставках оружия Сирии" (12.10.2012, http://www.kommersant.ru/doc/2042264) - исходное турецякоподданные; „Законоругатели. На встрече Владимира Путина с депутатами «акту Магнитского» досталось как следует" (14.12.2012, http://www.kommersant. ru/doc/2089366) - исходное законодатели; „Верховный главноиграющий. 7 октября президент России Владимир Путин встретил 63-й день рождения на хоккейной площадке во дворце спорта «Шайба» и отметил его семью голами в ворота сборной Ночной хоккейной лиги (НХЛ)" 
(07.10.2015, http://www.kommersant.ru/doc/2827182) - исходное (Верховный) главнокомандующий; „Заслуженный телеуйдущий. Гендиректор НТВ Владимир Кулистиков решил не продлевать контракт" (22.07. 2015, http://www.kommersant.ru/doc/2773234) - исходное телеведyщий. При заменительной деривции новообразования могут возникать в результате замены актуального или этимологического префикса: „Золотоумышленники. Госкорпорация «Внешэкономбанк» чуть не лишилась крупного месторождения в Читинской области" (06.12.2012, http://www.kommersant.ru/doc/2083694) - исходное золотопромышленники. Экспрессия новообразований, созданных путем заменительной деривации, усиливается в результате их каламбурного столкновения с исходными словами.

К сложным новообразованиям близки по структуре новообразования с аффиксоидами, среди которых преобладают префиксоиды заимствованного характера: „Телевыстрел мимо цели. Вторая «Анатомия протеста», как первая, реальную повестку дня заменяет мифологией" (08.10.2012, http://www.ng.ru/politics/2012-10-08/1_mimo.html); „Лавров проверил евроконтакты. Россия и ЕС продолжают взаимодействие, несмотря на кризис в отношениях" (Лента.ru, 20.05.2015, https://lenta.ru/articles/2015/05/19/eurominist/); „Еврояичница на российском газе. Молдавский премьер хочет получить от Москвы дешевые энергоносители и Приднестровье" (12.09.2012, http://www.mk.ru/ politics/2012/09/12/747921-evroyaichnitsa-narossiyskom-gaze.html); „Кибершпионы использовали уязвимость в ОС на компьютерах чиновников альянса" (14.10.14, http://newdaynews.ru/incidents/514941.html); „Иностранные кибершпионы активизировались в России" (14.05.2015, http://www.info-smi.ru/inostrannye-kibershpiony-aktivizirovalis-v-rossii/); „Пролетарии всех киберстран, объединяйтесь! На Глобальной конференции в Гааге даже Запад согласился, что с интернетом надо что-то решать” (18.04.2015, http://www.kommersant.ru/doc/2712459); „Кибервойска будут сформированы в Вооруженных силах Армении" (11.10. 2014, http:// ria.ru/world/20141028/1030527743.html); „Россия создает кибервойска" (05.08.2013, http://inosmi.ru/politic/20130805/211609091.html); „США и Россия создадут «горячую линию» для предотвращения случайной кибервойны” (19.06.2013, http://inosmi.ru/world/20130619/21 0205763.html); „США и Россия подписывают соглашение о создании линии связи по кибербезопасности" (18.06.2013, http://inosmi.ru/russia /20130618/210145773.html); „Пора всерьез отнестись к угрозе кибератак" (20.05.2013, http://inosmi.ru/world/20130520/209142744.html); „Наночистка. За что Анатолий Чубайс уволил две трети менеджеров «Роснано»" (25.05.2015, https://lenta.ru/articles/2015/05/25/rosnano/); 
„Нео-Сталин, нано-Путин и папаша Зюганов” (22.12. 2012, echo.msk.ru/ blog/ritty/974514-echo/).

В меньшей степени в российских электронных СМИ представлены новообразования с суффиксоидами исконного и заимствованного характера: „Ожидается лифтопад. Сегодня в России за лифты в подъездах и на производстве никто не отвечает" (15.03.2013, http://www.rg. ru/2013/03/15/lift.html); „ЧИсто теоретическая сексуальность этой девушки не вызывает в моем хорошо одетом организме никаких реакций: что бы там ни говорили фрейдоманы, простое человеческое сострадание все-таки сильней первобытного полового инстинкта" (16.02. 2012, http://expert.ru/russian_reporter/2012/06/homyachkam-holodno/); "Украинофилы готовы к автономии духовной” (16.05.2015. http://lenta.ru /comments/articles/2015/05/16/milukov/).

Сочетание префиксоида заимствованного характера с исконной основой способствует экспрессивизации новообразования (телевыстрел, еврояччница, кибервойска, кибервойна, киберстраны, кибербезопасность, наночистка), как и сочетание иноязычной основы с исходным суффиксоидом (лифтопад). Степень экспрессивности выше у новообразований, в которых иноязычный префиксоид сочетается с личным именем собственным (нео-Сталин, нано-Путин).

В современных электронных российских СМИ представлено большое количество неузуальных новообразований контаминированного характера, в которых произвольно совмещаются формально тождественные части исходных слов. Достаточно активно создаются новообразования с совмещением конечной части первого исходного слова и начальной части второго - так называемое междусловное наложение: „С футболью в сердце. Жеребьевка ЧМ-2018 была полна скрытых интриг и переживаний" (26.07.2015, http://www.kommersant.ru/doc/27 76789) - футбол + боль; „Троллевые игры. Сотрудник «фабрики интернет-ботов» добивается выплаты выходного пособия" (28.05.2015, http://www.kommersant.ru/doc/2736166) - троль + ролевые (игры); „Мимимитинг. Собачки, котейки и рыбки соберутся на митинг в Екатеринбурге под предводительством котенка-политика Бублика" (07.07.2012, http://ura.ru/news/1052143746) - мимими (выражение умиления в интернет-коммуникации) + митинг; „Вузы экстра-класстера: объединение высших учебных заведений должно идти по новому принципу" (27.12.2012, http://www.mk.ru/social/2012/12/27/793272vuzyi-ekstraklasstera.html) - экстра-класс + кластер.

В некоторых случаях одним из исходных слов для новообразования-гибрида является сложное слово или аббревиатура: „Физкультприветливые лица. Казань встретила Владимира Путина песней про любовь и золотом Универсиады" (20.03.2013, http://www.kommersant. 
$\mathrm{ru} / \mathrm{doc} / 2149958)$ - физкультпривет + приветливые; „Очень вузкие места. По каким правилам будут поступать в вузы абитуриенты-2016” (12.10. 2015, http://www.rg.ru/2015/10/13/postuplenie.html) - вуз + узкие.

В качестве исходных слов могут выступать варваризмы: „«Хэндехохма». В Берлине проект «Гражданин поэт» приняли за художественную самодеятельность" (07.12.2012, http://www.rg.ru/2012/12/07/ poet.html) - хендехох + хохма.

При гибридизации возможны разного вида формальные видоизменения исходных слов, в частности чередования, замены графем: „Росгосстрашное предупреждение. Как Центральный банк и страховщики пугают друг друга" (27.05.2015, https://lenta.ru/articles/2015/ 05/26/rosgos/) - pосгосстрах (Российское государственное страхование) + страшное. Возможно усечение начальной части второго слова: „Прыжок из тратосферы. Ближайшие три года Белый дом намерен расходы только сокращать" (21.10.2015, http://kommersant.ru/doc/ 2836627) - траты + стратосфера; „Убедителей не судят. Как Владимир Путин и Франсуа Олланд нашли друг друга" (26.11.2015, http:// kommersant.ru/doc/2863010) - убедить + победителей (не судят); „Хроники кипроприации: на остров сбросили гуманитарный груз - пять миллиардов евро наличными" (29.03.2013, http:// www.novayagazeta. ru/economy/57427.html) - Kunр + экспроприация. В некоторых случаях усекается конечная часть первого исходного слова: „С лихорадостным настроением встречали Новый год члены правительства с Владимиром Путиным" (14.01.2016, http://www.kommersant.ru/doc/2890868) - ^uхорадочно + радостныи; „Убеженец. Как Джулиан Ассанж обхитрил англосаксонский истеблишмент и что ему за это будет" (20.08.2012. http://www.rusrep.ru/article/2012/08/20/ubezhenec/) - убежище + беженеи; „Контрабатькин товар. Белоруссия продает российскую нефть на Запад под видом растворителей" (12.10.2012, http://www.mk.ru/politics/ article/2012/10/11/760197-kontrabatkin-tovar.html) - контрабанда + батькин; „Фармагеддон не за горами. Новые импортные лекарства в 2016 году не будут допущены на российский рынок" (29.01.2016, http://kommersant. $\mathrm{ru} / \mathrm{doc} / 2902728)$ - фарма + армагеддон; „Как дагестать богатым. Минкавказа предлагает отдельно финансировать Дагестан" (16.05.2015, http://www.kommersant.ru/doc/2728297) - Дагестан + cmamb.

В качестве исходных слов могут выступать аббревиатуры: „Незачоп. В МВД считают, что время, когда иные «новые русские», среди которых - криминальные лидеры, создавали под видом ЧОПов и разношерстных "служб безопасности» частные армии, почти прошло" (02.04.2013, http://rg.ru/2013/04/02/nezachop.html) - незачет + ЧОП; „Росгосстрашное предупреждение. Как Центральный банк и страховщики пугают друг друга" (27.05.2015, https://lenta.ru/articles/2015/05/ 
26/rosgos/) - poсгосстрах (Российское государственное страхование) + страшное; „Бомжья благодать. Двадцать два года на улице. Трагическая история Алевтины Укустовой" (21.05.2015, http://www.mk.ru/social /2015/05/21/dvadcat-dva-goda-na-ulice-tragicheskaya-istoriya-alevtinyukustovoy.html) - божья + бомж (без определенного места жительства).

В последнем случае одно из исходных слов вставляется внутрь другого, в подобных случаях ученые говорят о тмезисе: „Туркоператоры. Российский МИД не рекомендует гражданам посещать Турцию" (24.11.2015, http://rg.ru/2015/11/25/tur.html) - mуроператоры + турки; „Шпионообмания. Правозащитники просят президента не вводить общество в заблуждение насчет их агентурных связей с заграницей" (01.10.2015, http:// kommersant.ru/doc/2822586) - шпиономания + обман; "Удоверовал. Владимир Путин закрепил за собой 500 доверенных лищ" (11.12.2012, http://www.kommersant.ru/doc/2087256) - ybeровал + доверенное (лищо); „Пресс-президенция. Владимир Путин показал себя таким, каким решил показать" (21.12.2012, http://www.kommersant. $\mathrm{ru} / \mathrm{doc} / 2094748)$ - пресс-конференция + президент; „Торпедовыносцы. Поставки запчастей дали материал для нового дела против «Оборонсервиса»" (06.02.2013, http://www.kommersant.ru/doc/2121241) - mopneдоносиы + выносить (вынос); „Заофшоренные. Российские бизнесмены, не платящие налоги в России, будут лишены важных возможностей" (27.12.2012, http://www.rg.ru/2012/12/27/ofshor.html) - зашоренные + офшор.

Сложные новообразования неузульной словообразовательной структуры по-разному определяются, терминируются в российской лингвистике: слово, созданное путем междусловного наложения (И.А. Янко-Триницкая), новообразования-гибриды (Л.В. Рацибурская), контаминированные образования (Е.А. Земская). В силу ярко выраженной неузуальности их структуры подобные гибридные новообразования характеризуются высокой степенью экспрессивности и служат действенным средством воздействия на сознание носителей языка.

К дискурсивным средствам экспрессивизации сложных новообразований относятся прецедентные феномены, в частности прецедентные тексты, „значимые для той или иной личности в познавательном и эмоциональном отношениях, имеющие сверхличностный характер, т. е. хорошо известные и широкому окружению данной личности, включая ее предшественников и современников" ${ }^{3}$. Прецедентные тексты и, шире, феномены хорошо известны „всем представителям национально-лингво-культурного сообщества”, актуальны „в когнитивном (познавательном и эмоциональном) плане" 4 . Медийщики давно

${ }^{3}$ Ю.Н. К а р а у л о в, Русский язык и языковая личность, Москва 1987, с. 216.

4 В.В. К р а сных, „Свой” среди „чужих": миф или реальность, Москва 2003, с. 170. 
активно обыгрывают прецедентные феномены при создании новообразований: Верховный главноиграющий (ср. устойчивое сочетание верховный главнокомандующии), Пролетарии всех киберстран, объединяйтесъ! (ср. марксистский лозунг Пролетарии всех стран, объединяйтесь!), вузкие места (ср. фразеологизм узкое место), троллевые игры (ср. устойчивое сочетание ролевые игры), убедителей не судят (ср. фразеологизм победителей не судят), бомжъя благодать (ср. фразеологизм божья благодать). Удачное словотворчество способствует

акцентированию внимания читателя на актуальных общественных проблемах, актуализирует имеющиеся у читателя культурологические знания и лингвистические представления о связях языковых единиц и способствует расширению образовательного пространства в современном обществе 5 .

Следует также отметить активное использование медийщиками новообразований в заголовках электронных текстов в информационно-развлекательной функции: с целью заинтересовать адресата, привлечь его внимание к публикации и в определенной степени, частично намеком, информировать о содержании текста.

Для заголовочных новообразований [...] актуальной [...] является проблема адекватного истолкования читателем, степень информативности: заголовок, как правило, не поясняет новообразование, расшифровка окказионализма во многом базируется на анализе его структуры. Заголовочные новообразования могут иметь определяющее значение в процессе отбора публикаций читателем ${ }^{6}$.

В тех случаях, когда заголовок не очевидно коррелирует с содержанием текста, новообразования не производят необходимого коммуникативного эффекта („Хэндехохма”, ,"Удоверовал”, „Незачоп”).

Таким образом, сложные новообразования в электронных российских СМИ различаются по характеру их словообразовательной структуры (стандартная/нестандартная) и по способам словообразования (узуальные / неузуальные). Структурно-семантическая специфика сложных новообразований влияет на степень их экспрессивного воздействия на сознание адресата. К факторам, способствующим экспрессивизации сложных новообразований, относятся нестандартность их деривационной структуры, неузуальные способы их создания, неузуальные сочетания составляющих новообразования частей, обыгрывание прецедентных феноменов.

5 Л.В. Р а ц и б у р с к а я, Н.А. С а м ы л и ч е в а, А.В. Ш у м и л о в а, Специ фика современного медийного словотворчества, Москва 2015, с. 84.

6 Там же, с. 92. 


\section{Библиография}

И л ь я с о в а С.В., А м и р и Л.П., Языковая игра 8 коммуникативном пространстве СМИ и рекламы, Москва 2015.

К а р а у л о в Ю.Н., Русский язык и языковая личность, Москва 1987.

К ра с ны х В.В., „Свой” среди „чужих”: миф или реальность, Москва 2003.

Р а ц и б у р с к а я Л.В., С а м ы л и ч е в а Н.А., Ш у м и л о в а А.В., Специфика современного медийного словотворчества, Москва 2015.

Т о ш о в и ч Б., Интернет-стилистика, Москва 2015. 